University of Nebraska - Lincoln

DigitalCommons@University of Nebraska - Lincoln

Faculty Publications: Department of Teaching, Department of Teaching, Learning and Teacher Learning and Teacher Education

Education

$1-2008$

\title{
From Nuevo León to the USA and Back Again: Transnational Students in Mexico
}

\author{
Edmund T. Hamann \\ University of Nebraska-Lincoln, ehamann2@unl.edu \\ Víctor A. Zúñiga \\ Universidad de Monterrey, vazgonzalez@itesm.mx \\ Juan Sánchez Garcia \\ Escuela Normal "Miguel F. Martinez", juansg@intercable.net
}

Follow this and additional works at: https://digitalcommons.unl.edu/teachlearnfacpub

Part of the Anthropology Commons, Bilingual, Multilingual, and Multicultural Education Commons, Demography, Population, and Ecology Commons, International and Comparative Education Commons, Race and Ethnicity Commons, and the Teacher Education and Professional Development Commons

Hamann, Edmund T.; Zúñiga, Víctor A.; and Sánchez Garcia, Juan, "From Nuevo León to the USA and Back Again: Transnational Students in Mexico" (2008). Faculty Publications: Department of Teaching, Learning and Teacher Education. 79.

https://digitalcommons.unl.edu/teachlearnfacpub/79

This Article is brought to you for free and open access by the Department of Teaching, Learning and Teacher Education at DigitalCommons@University of Nebraska - Lincoln. It has been accepted for inclusion in Faculty Publications: Department of Teaching, Learning and Teacher Education by an authorized administrator of DigitalCommons@University of Nebraska - Lincoln. 


\section{From Nuevo León to the USA and Back Again: Transnational Students in Mexico}

\author{
Edmund T. Hamann \\ Víctor Zúñiga \\ Juan Sánchez García
}

KEYWORDS. Transnational students, Nuevo León, reverse migration, immigrant students, Mexican education, U.S. education

\section{INTRODUCTION}

In November and December 2004, by surveying 14,444 students in their classrooms in the state of Nuevo León Mexico, we found 242 students in primaria or secundaria (elementary or middle school) who had previously attended U.S. schools. They were enrolled in one of the randomly selected classrooms in the 173 randomly selected schools that our team visited across the state. From our sample, we project that at the end of 2004 there were between 9,371 and 10,357 transnational students enrolled in primaria or secundaria in Nuevo León (Mexico) who had previously attended school in the United States. This paper describes those students and the under-heralded category that they compose: transnational students in a migrant sending country. Students in our sample are part of a new phase of American and Mexican school and migration history and they form a sizeable and particular subset of the transnational population that moves between these two countries. Since the 1965 changes in American immigration law and even more so since the Immigration Reform and Control Act (IRCA) of 1986, both who goes to work and who goes to school in the United States and Mexico has changed. Schools are "mediating institutions" of immigration (Goode, et al. 1992; Lamphere, 1992)-i.e., sites where local contexts interface with international-scale macro-social dynamics. Today in the United States, not only is the Latino school enrollment increasing, but more specifically "Children from Mexican immigrant families represent one of the fastest-growing populations in the American educational system" (Crosnoe, 2005,). Zehler et al. (2003) estimated that there were 918,600 K-12 students in U.S. schools in 2001-2002 who were identified English language learners (ELLs) and who were born in Mexico (another portion of the U.S. K-12 population was born in Mexico but is sufficiently proficient in English to not be identified in an ELL tally). These Mexican-born students are in California, Texas, and Illinois, but they are also in North Carolina, Georgia, Rhode Island, Nebraska, Alabama, Idaho, Iowa, and elsewhere (Cuadros, 2006; Hamann, 2003; Wortham et al., 2002; Zúñiga \& Hernández, 2005). The presence of Mexican-born students in the U.S. schools is increasingly a national phenomenon and is likely to be part of a long-term change in which Mexican-descent inhabitants permanently compose a portion of many locales' populations.
Journal of Immigrant \& Refugee Studies, Vol. 6(1), 2008
Available online at www.haworthpress.com

(c) 2008 by The Haworth Press. All rights reserved. doi: $10.1080 / 15362940802119245$ 
Yet the story of the students we met is only indirectly a story about the U.S., about what these students used to experience in school north of the Border. It is more a story about Mexico and about students there whose biographies and trajectories are not well anticipated by current school praxis as evidenced by the need for so many of them to repeat years of schooling. Today, Mexican schools are not only losing potential students to northward migration, they are also receiving transnational students from the United States. These are students who look Mexican in appearance, whose parents may be Mexican, but who may not be fully proficient in Spanish, who may not have been socialized to Mexican expectations of the student/teacher relationship, and who may even be U.S. citizens by virtue of a U.S. birth.

As López Castro (1999) pointed out:

Teachers in the schools districts located in regions with high international rates in Mexico (Michoacán, Guanajuato, Jalisco, and Zacatecas) are facing learning practices that they do not understand or simply do not accept, forms of evaluation that they are not familiar with, standards of school success that they do not value; all this is more complicated because the low Spanish proficiency of their students ... it is not exceptional to see 4 th grade teachers forced to accept kids in their classrooms who do not know read nor write [in Spanish].

We would only add that many teachers in Nuevo León are also negotiating this dynamic. Transnational students are coming to Mexico because their parents have realized the financial goals that precipitated their original migration, or to accompany or reunite with deported parents, or to live away from the perils of many American communities (e.g., gangs and violence), and/or as part of a family migration to reconnect with/care for other family members still in Mexico. In this 'return' migration, they are like the smaller numbers of students of Puerto Rican descent who return to Puerto Rico (e.g., Serrano, 1998; Reyes, 2000), of Dominican descent who return to the Dominican Republic (e.g., Garcia, 1999), and so on. These students and their families are engaged in a dynamic that several authors have called "transnationalism from below" (Hamann, 2001; Hamann, Zúñiga, \& Sánchez García, 2006; Smith \& Guarnizo, 1998). Participants in this dynamic balance aspiration, need, risk, affiliation, and responsibility by using both sides of the Border. In so doing, they negotiate and define transnational facts.
Transnational facts, according to Glick-Schiller (1999), relate to "processes that extend beyond the borders of a particular state, [that] include actors that are not states, but are shaped by the policies and institutional practices of states." Students in our sample, the projected 10,000 like them in other Nuevo León schools, and the perhaps hundreds of thousands like them elsewhere in Mexico have been negotiating and creating transnational facts as they have been socialized in a transnational social field.

For more than one hundred years in Mexico, migrants to the United States were typically adults who moved alone, leaving their families in Mexico (Goméz de León \& Tuirán, 2000). In high density Mexican migration regions, traveling to the United States after finishing one's formal schooling (and then coming home after a stint) even became an adolescent males' rite of passage into adulthood (Brettell \& Hollifield, 2000; Massey et al., 1987). But these migratory patterns substantively changed when the Immigration and Control Reform Act (IRCA) was adopted by the U.S. Congress in 1986.

IRCA allowed 2.3 million Mexican migrants to get legal residency in the U.S. and eased their movement from the traditional Mexican-receiving gateways in California, Texas, and Illinois (Massey, Durand, \& Malone 2002; Zúñiga \& Hernández-León, 2005; Gozdziak, 2005). At the same time, IRCA tightened and increasingly militarized border controls, a process that continues to the present (Dunn, 1996; Massey et al., 2002), which impeded frequent cross-border movement by those without papers. Temporary migration became harder just as the economic impetus to migrate became more acute. In 1993 the North American Free Trade Agreement (NAFTA) accelerated Mexican participation in international migration because of the rural economic dislocations precipitated by NAFTA's reduction of price protection for Mexican maize farmers. Post-IRCA and NAFTA, an increasing number of Mexican newcomers have elected to stay longer in the U.S. and to live there with their families and/or to start their families there. Passel (2006, p. ii) recently estimated that there are 3.1 million U.S.-born children living in unauthorized families in the U.S. (i.e., with at least one undocumented parent) and another 1.8 million children who themselves are undocumented. With Mexico supplying $56 \%$ of the U.S. unauthorized population (Passel, 2006, p. i), his data suggest there are millions of highly dislocatable minors of Mexican background in the United States. Meanwhile, because of IRCA (and other legalization means) there are also millions of children with Mexican-born parents who are part of authorized households in the United States. Though less dislocatable, this 
population too is likely a source of the students with U.S. school experience that we found in Mexico.

Thus, this new Mexican migratory stream is much more involved in U.S. schools than those previous. But unlike the conceit in the United States, that presumes all newcomers intend to be immigrants (even if that has never been the case [Súarez-Orozco \& Súarez-Orozco, 2001]), the postIRCA/post-NAFTA migratory flow has been neither entirely unidirectional nor stable. In other words, it has included a flow (back) into Mexico. This is the context for this article. For the first time, we have quantitative and qualitative data from a randomized sample of transnational students from an entire state in Mexico that allows us to describe the experiences, identities, and perceptions of Mexican transnational students.

\section{Constructing Transnational Schooling as Scientific Subject}

Social scientists have recently directed their attention to the simultaneous incorporation of transnationals into both their states of origin and new settlement (e.g., Kearney, 1996; Guarnizo, 1997; Goldring, 1992; Pessar, 1995; Smith, 1998; Smith \& Guarnizo, 1998; Pries, 1998; VelascoOrtiz, 2002). Guerra (1998) describes transnational communities where full membership in the community requires familiarity with and being of more than one geographic location. As Glick-Schiller (1999) and VelascoOrtiz (2002) have observed, in this new subfield of analysis anthropologists have adopted a new research paradigm and changed the unit of analysis. What they did was to separate "their concept of society from their concept of national territory. They moved outside of the dominant imagery of the nation-state, which contains the expectation that polity, territory, and society coincide" (Glick-Schiller, 1999).

Transnational ties and identities are not new. What is new is this geocultural perspective to describe them. Why was it necessary to move from dominant nation-state imagery to a transnational standpoint to see the multiple locales and culture-scapes of migrant people? Because transnational fields and lives are often invisible, or, to put it the terms used by the students we surveyed and interviewed, many of these students did not feel only Mexican. The continued transnationalism of transnational students in the United States is often invisible for teachers and principals until they leave. The teachers in Valdés' (2001) Learning and Not Learning English lament the typical case of 'Juana', a newcomer student toward whom substantive assessment and planning investments are made (assuming she is an immigrant) and then wasted, when after six weeks she unexpectedly leaves. In Mexico, when such students return/arrive, their Spanish surnames and phenotypical "Mexicanness" often make their transnationalism invisible again (Lopez Castro, 1999; Sánchez García, 2007). Yet lack of facility with Spanish and lack of familiarity with Mexican school customs mean at least some of these students struggle (Hamann et al., 2006).

Most of the teachers of transnational students in the United States and Mexico are not trained or expected to explicitly build on the "funds of knowledge"-i.e. the personal, familial, and communal experiences and backgrounds that students bring with them to school and that could be resources for teachers to help students to make sense of the world and their academic tasks (Gonzalez et al., 1995; Gonzalez, Moll, \& Amanti, 2005; Moll, Tapia, \& Whitmore, 1993). Planning time is not allocated for teachers to prepare to differentiate their instruction in ways responsive to students' different biographies and little training is offered regarding how to work most successfully with English learners in the U.S. (Gándara, Rumberger, \& Callahan, 2003) or with Spanish learners in Mexico (Sánchez Garcia, 2007).

Literature on transnational students emphasizes their vulnerability and frequent school failure (Crosnoe, 2005; Hamann, 2001; Trueba, 1998). Certainly, they encounter a number of obstacles in their schooling-language barriers, poverty, disjointed school experience, curriculum discontinuities, and, psychological stress (Suárez-Orozco \& Suárez-Orozco, 2001). Yet some clearly learn how to take advantage of the multiple schooling processes and the fragmented contexts they experience in the early years of their life. These students' schools may not be transnational, but these students are. These transnational students learn to negotiate multiple contexts with little time for transition. They acquire the ability to read different and contradictory codes. They understand that social orders are not natural but arbitrary. Some of them become bilingual and binational (Petrón, 2003). The key seems to be whether they get caught between two worlds or become of the two; the latter is a key asset in our increasingly globalized world (Hamann, 2001).

\section{State of Nuevo Leon: Methodology and Sample}

Nuevo León is one of the most industrialized and wealthiest regions in Mexico. Located in the northeast of that country, Nuevo León shares a short border with Texas and long borders with the Border States of Tamaulipas and Coahuila. Its capital, Monterrey, has had strong commercial relations with Texas since 1860 . Nuevo León also shares the same topography as 
South Texas (hot agriculturally rich plains) and West Texas (a striking southern extension of the Rocky Mountains). These factors help explain why, in the second half of the 19th century, it was easier for Monterrey to have trade with Texas than with major Mexican population centers. San Antonio and Houston are closer to Monterrey than are Mexico City and Guadalajara. These factors also explain why Nuevo León is a longstanding participant in international migration. Despite this proximity to the United States and the history of economic ties and migration between Nuevo León and the American states to its north, most of Nuevo León is not classified as having high participation in international migration flows to the United States. Only two out of Nuevo León's 31 municipios (counties) have been classified as having high or very high density of international migrant households by CONAPO-Mexico's Federal Council of Population (Tuirán et al., 2002). Nonetheless, Nuevo León made for a good research site for several reasons. In addition to having our best contacts there (because two of the three authors of this article call Monterrey home), Nuevo León has received less attention than other historic states that have higher migration densities (e.g., Michoacán, Guanajuato, and Jalisco). We felt that if we could show that transnational migration of students was an issue for Nuevo León schools then, by extrapolation, it should be even more of an issue in these higher density regions. ${ }^{1}$ Moreover, Nuevo León's heterogeneity is like that of other parts of Mexico-it has pockets of high migration, it has large and rapidly growing cities (i.e., Monterrey), and it has economically fragile small towns- towns where economic vulnerability precipitates population movement. Because of this heterogeneity and a sampling strategy that assured representation in low, medium, and high migration density municipios, we were able to see if there was a correlation between migration rates for municipios and percentages of transnational students. There was, and we suspect on this dimension too that what we found in Nuevo León is similar to what occurs elsewhere in Mexico.

Public and private school systems in Nuevo León enrolled 704,604 students in the school year 2004-2005 distributed as follows: 497,795 were enrolled in the 2,528 escuelas primarias (1st-6th grades) and 206,809, in the 782 escuelas secundarias (7th-9th grades). From this universe of schools, we selected a stratified representative sample of 173 schools, taking into account level of education (90 primarias and 83 secundarias), degree of international migration density according to CONAPO classification, and rural/urban location. This last indicator was very important because almost $90 \%$ of the population in Nuevo León lives in the Monterrey metropolitan area and we weighted our sample to make sure we had adequate representation of rural schools for comparative purposes. Twenty-two of the schools in our sample were private ( 6 primarias and 16 secundarias) and the rest were public. In Nuevo León, according to federal statistics, in 2003-04, 90.1\% of the eligible population attended primaria, $91.1 \%$ of the eligible population attended secundaria and $55 \%$ of the eligible population attended preparatoria (grades 10 to 12) (Secretaria de Educación Pública, 2004). Attending preparatoria is not compulsory in Mexico (so we did not study preparatorias), but primaria and secundaria are. Though we collected data from approximately 700 classrooms, including some from the early grades of primaria (i.e., grades $1-3$ ), in this article we primarily use data from the 208 transnational students we found in grades 4 through 9 . (Even when children attending early grades know that they studied in the United States, they often cannot reliably answer where they studied, how many years, and other important indicators of their school trajectories.) Our database of students grades 4 to 9 includes 10,062 cases. From that sample, we found 208 transnational students (2.1\%) and $9,854(97.9 \%)$ who never studied in the United States. Among the transnational students, $76 \%$ were born in Mexico and $24 \%$ in the United States. Thus at least $24 \%$ of the transnational students were U.S. citizens because of their place of birth. We also found students who were born in the United States but never attended American schools. Adding this population to the U.S.-born transnational student population it appears that almost one percent of Nuevo León's public school enrollment is composed of U.S. citizens. $^{2}$

We applied two types of questionnaires. One was used for all the students and the other exclusively for transnational students. Additionally, we interviewed 46 transnational students and transcribed those interviews. Because our research was all school based, our survey and approach did not find and did not count the number of school-eligible Mexican youth with U.S. school experience who did not enroll. Because of this possible 'missed population', we recognize that our study may show a more optimistic picture of schooling of U.S./Mexico transnational students than is warranted.

\section{Towards Three Typologies of U.S.-Mexico Transnational Students}

All of the transnational students we found in Nuevo León shared two characteristics: They were enrolled in a Mexican school and they had previously enrolled in a school in the United States. Nonetheless, in spite 
of these shared characteristics, the 208 older transnational students varied substantively in terms of previous school experience and success, number of schools they had attended in the United States, conditions of their current and previous schools, and in other ways. We begin our review with the most obvious indicators: Country of birth and its relation to school experience. Most transnational students in our sample were born in Mexico, began their schooling in Mexico, continued it in the United States, and have more recently come back to Mexico. Others were born in the United States, began their schooling in the United States, and later came to Mexico. Yet others were born in Mexico, began their schooling in the United States, and now are again in Mexico. Still others were born in the United States, began their schooling in Mexico, then went back to the United States before resuming their studies again in Mexico. This variety of trajectories shows that transnational students' experiences are neither linear nor synonymous. They also highlight issues we had not anticipated with our questionnaire, like the 9th grade student who protested that she could not answer the questionnaire because she could not say which years she had been in the United States and which ones in Mexico; she explained "Every year I go to the United States and later come back to Mexico." She could not offer a sum of years in one location or the other. She was experiencing an entirely bi-national education, year after year.

The different trajectories mean that different portions of our sample are more or less similar to transnational students elsewhere. For example, in the European Union now several countries (e.g., Britain) permit movement between member nations and the experience of students who had legally been in the U.S. before coming to/returning to Mexico would be akin to students from a Polish family that had legally moved to Britain to work before returning to Poland. For others in our survey (e.g., students born in Mexico) many may well have attended school in the U.S. as unauthorized immigrants with unauthorized parents, their return to Mexico could be akin to the return of students to Cape Verde or to a sub-Saharan African nation after a stint in Europe. Research on migration in Europe is wellestablished and longstanding, including a literature on immigrant students, but we expect that our claim that the study of U.S./Mexico transnational students in Mexico is covering under explored ground would find a parallel in the still rather new field of child migration studies-how do students who negotiate schools in migrant receiving countries negotiate schools upon return in countries better know for being migrant sending locales?

Some of the students we interviewed and surveyed had undergone the majority of their schooling in the United States. Others had matriculated primarily in Mexico. Still others had spent approximately equal time in the systems of both countries. On this dimension of number of systems that students have experience in, we observe a diverse configuration of fragmented and distinct experiences. One of our sample, a student in his last year of secundaria (ninth grade) had been born in Río Grande City, Texas, had attended kindergarten through grade 6 in Hampton, South Carolina, seventh grade in Athens, Georgia, and then 8th grade and the first part of ninth in Monterrey. Paradoxically, his experience was unique (the only Texas to South Carolina to Georgia to Mexico experience in our sample) and yet not atypical (many students had moved within the United States before coming to Mexico). He considered English his first language and he wanted to continue his studies in the United States, but he did not see that as very likely. He knew that his parents had little interest in returning to the United States.

Other transnational students did not have educational biographies showing quite so much mobility. Their school years on one side of the Border were at least modestly recognized on the other. Such students attended, for example, first grade in Mexico, second grade in the United States, and then third grade back in Mexico, without delay or repetition. But delays and repeated years of schooling were common in our sample. Particularly common was repeating a year at the Mexican end, where it was more likely that U.S. school experience would not be recognized and/or that a student's Spanish capability was inadequate for the grade level they otherwise would be eligible for. (Nineteen of the transnational students had repeated a year upon arriving/returning to Mexico, or 9.2\%). All of the students who had repeated a year because of transnational movement were older than most of their grade-mates; transnational mobility had delayed their academic progression.

Most of the transnational students in our sample were in Mexico living with their parents (79\% were living with both) and had also been with their parents and siblings in the United States (93.4\% had been with their parents in the U.S.). But there were students in our sample who were living with relatives in Mexico while their parents continued to labor in the United States (18\% reported that their father was still working in the U.S. and $3 \%$ said both their father and mother were working in the U.S.).

Our data on why students had come back to Mexico without both parents comes from interviews, not surveys, so we cannot say whether this kind of "return" regularly indicated parents' judgment of the United States as dangerous or immoral, themes explored by Hagan (1994) and Reese (2002), but this does seem to have sometimes been the case. An eighth 
grade girl who had been born in Houston reported that she was attending secundaria in Monterrey because her mother had sent her there, explaining, "The environment in Mexico is better than that of the United States." The girl clarified that, "I don't agree with my mother" and stated her intention of returning to Texas after she completed preparatoria (grades 10 to 12) in Mexico. ${ }^{3}$ Nonetheless, she had obeyed her mother and was living in Mexico with her grandmother.

We did not gather survey data on the nationality of the parents of transnational students (one can wonder how reliably students could offer such information), but we can suppose that the vast majority of such parents were of Mexican nationality, born in Mexico. We also do not have survey data on the economic activity of parents and other household members when they were with the transnational students in the United States, but we can see hints of variations in the livelihoods of the families of transnational students based on where in Nuevo León we found them. We found a number of transnational students in public schools in the metropolitan zone of Monterrey; we can conjecture that the bulk of such students were parts of household involved in industry or the service sector (the major employment niches in Monterrey). In private schools in Monterrey we found another group of transnational students; students who reported their parents were doctors, professors, and engineers. One girl in her final year of secundaria explained, "We came back [to Mexico] because my mother is a teacher at a school in Monterrey and she had to return here or she would have lost her retirement benefits." ${ }^{4}$ Disproportionate portions of our sample (more than $40 \%$ ) lived in villages and small towns in Nuevo León and were enrolled in venerable but resource-poor rural schools (INEE 2004). We can suppose that the families of most of these students were involved in low-skill work in the United States. Collectively, our study reveals that transnational students in Nuevo León are a diverse group in terms of educational history, school environment in Mexico, and socio-economic background.

If variety is the most distinct characteristic of our sample, that does not mean we cannot specify typologies and various patterns associated with them. We identify three. The first type, Profile A, includes students born in the United States who began their schooling there and later moved to Mexico. They compose almost a quarter of the sample (23\%). Second we have Profile B, the cases of students born in Mexico who had one stint in U.S. schools (whether they started in kindergarten there or came later) before returning to Mexico. They form two thirds of our sample $(66 \%)$. Finally, we have Profile C, students who have moved various times between schools in both countries. They formed a little more than a tenth of our sample $(11 \%)$.

Profile A: Students Born in the United States who later go to Schools in Mexico

As one might guess, most of the transnational students in our sample who were born in the United States began their schooling in the United States. These students were also the ones who averaged the most amount of time in U.S. schools (See Table 1). A plurality of these 'Profile A' students was born in Texas (42\%), and another $20 \%$ were born in California. But the remainder came from a variety of U.S. locations: Oregon, Illinois, New York, Florida, Washington, Georgia, Kentucky, Minnesota, and Oklahoma.

At the time of our survey (November and December 2004), $41 \%$ of the Profile A students continued to have close family members (siblings, parents, and/or grandparents) who lived in the United States. Usually it was a father who was still in the United States, often accompanied by a transnational student's older brother or sister. We found a few cases where some of the students in our sample had siblings currently attending grade school in the United States, but in most of the instances where siblings were not together, work opportunity was the explanation-i.e., the older sibling was done with school and was working in the U.S. According to the indicators of school success that we used (which had the real limitations of being self-reported), all of the Profile A students had done well in the United States. The majority had received good grades; most considered their teachers to be "good" or "excellent." These favorable impressions may help explain why the majority wanted to return to the United States.

But delays in educational experience in Mexico may have been another motive. The Profile A sample averaged .4 years of delay in terms of age and grade level. Looked at another way, almost half of the Profile A sample had been delayed in some way in terms of their educational trajectory. In some cases this was because students had begun their schooling at a slightly older age than usual. More commonly, however, the delay was product of repeating a grade upon arriving in Mexico. As one principal explained to us when describing a student who attended third grade in Mexico after completing third grade in the United States, that student needed stronger Spanish before being ready for fourth grade. Few Mexican schools have even an informal capacity to directly support students with limited proficiency in Spanish, so a frequent de facto strategy is to have students negotiate the easier academic content of earlier grade levels. More 


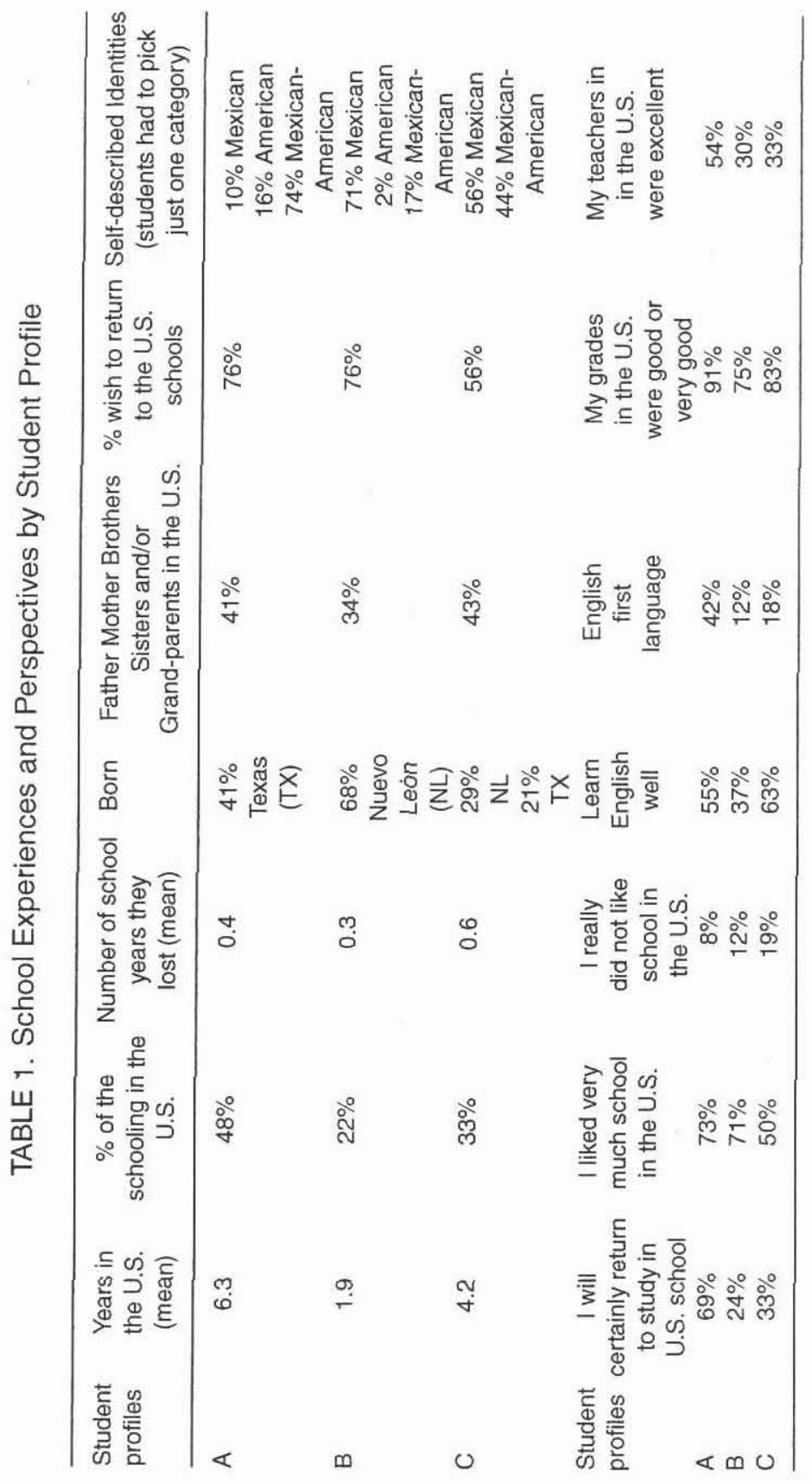

than half of the Profile A students asserted that they spoke English well, and four tenths characterized English as their first language. Only four $(8 \%)$ of the Profile A students indicated that they had no desire to return to their land of birth, the United States.

\section{Profile B: Students Born in Mexico Who Later Go to the U.S. Before Returning}

Profile B students (students who were born in Mexico but later attended school in the U.S. before coming back to Mexico) had, on average, spent much less time in U.S. schools than the Profile A students. The average duration of their U.S. school experience was 1.9 years, about a fifth of their total scholastic experience to date. Per this second point, it follows that those in this category who had completed more years of schooling (e.g., those who were in their second or third years of secundaria) had also averaged more time in the U.S. than those in this group who were younger and in earlier grades. Perhaps the relative brevity of time in U.S. schools among this group explains why fewer of them had been delayed in terms of their age and grade-level progress than students of either Profile A or C.

The relative brevity of time in U.S. schools helps explain why Profile B students indicated they had less command of English than did Profile A or Profile C students, and very few Profile B students (12\%) indicated that English was their first language. In turn, perhaps this relatively limited command of English helps explain why Profile B students were less likely to indicate that their U.S. grades were good, although three quarters still felt that they had done well in the United States.

Profile A and Profile B students were equally likely to say they hoped to return to study in U.S. schools again (not shown in Table 1), but Profile $\mathrm{B}$ students were much less confident that they would someday do that than either Profile A or Profile C (as shown in Table 1). Those in Profile B who were more likely to indicate an expectation that they would again study in U.S. schools were those who had a close family member living and working in the United States at the time of our survey. The presence of relatives in the United States makes a return easier.

The majority of Profile B students were born in Nuevo León (68\%). Nevertheless the proportion (32\%) from elsewhere in Mexico is important. There were transnational students in Nuevo León who had been born in Mexico City and the Mexican states of Chihuahua, Sonora, Tamaulipas, Coahuila, San Luis Potosí, Jalisco, Veracruz, and Michoacán. These students clearly are part of a multi-location bi-national migration flow (and 
form an understudied subcategory of U.S./Mexico transnational migration). Their story also hints at another dynamic in parts of Nuevo León, that complicates Nuevo León schools' response to transnational students. Several schools in Nuevo León, particularly those in lower-income colonias on the periphery of Monterrey, host high proportions of internal migrants (i.e., students whose families have migrated from elsewhere in Mexico attracted by the relatively robust economy of Monterrey). Often such students live in high mobility neighborhoods distant from extended family and other social networks. When many students are from somewhere else, the particular experiences and orientations of transnational students are even easier to ignore/lose track of. Internal and transnational migration overlap with each other and complicate each other.

Given their country of birth, as one would expect most Profile B students consider themselves "Mexican." However, a surprisingly high percentage, more than one in six (17\%), self-identified as "Mexican-American" and a few even identified (1.9\%) as "American" ("estadounidense"). This suggests that the circumstances that compel transnational students to adopt a nation-related identity are complicated and do not derive exclusively from place of birth, nor the length of transnational experience.

\section{Profile C: Students Who have Experienced Multiple Border Crossings}

Profile $C$ students are those with the most fragmented or interrupted collection of transnational experiences. Some were born in the United States, began their schooling in Mexico, returned to the United States, and then returned again to Mexico. Others were born in Mexico, began their schooling in the United States, returned to Mexico, returned to the United States, and then were back in Mexico (in Nuevo León) at the time of our school visits. Within Profile $\mathrm{C}$ are many students who have been enrolled in schools in both countries within the same academic year. Profile $\mathrm{C}$ also includes those transnational students whose U.S. school experience was most geographically fragmented - i.e., many changed schools and districts during their stints in the United States, suggesting the mobility/dislocatability of the households they were part of. In one case we recorded, a 7th grade student (first year of secundaria) who had been born in Nuevo León went to first grade in Orlando, Florida, attended second and third grades in Nuevo León, attended fourth grade in Atlanta, then repeated fourth grade in Nuevo León where she had remained enrolled ever since. She identified herself as "mexicana" but also indicated that she hoped to return to the United States. On average, Profile C students had spent a third of their time in school in U.S. schools and two-thirds in Mexico. But this average is misleading in that it obscures wide variation. Some of the Profile C students in our survey had spent more than $70 \%$ of their time in school in U.S. schools; others had been enrolled there for less than $20 \%$ of their total experience. Profile $\mathrm{C}$ students had a wide variety of educational biographies.

The fragmentation of Profile C students' school experience suggests an explanation for their having less desire to return to U.S. schools than either Profile A or Profile B students (only 50\% indicated such a desire while more than $70 \%$ of Types A and B did). Profile C students reported high levels of competence in English and also reported that their U.S. grades were good or very good, but their experiences in any given U.S. school were typically so short lived that they could not as readily have been known as well by a teacher as more geographically stable students; they would not have had as much of a chance to develop friendships and networks with peers; and they would have been even more likely to encounter curricula that was not aligned with their previous school experience (somewhere else). In short, their reduced interest in returning to U.S. schools could be less a product of school failure there (though it is possible their self-reported performance was more optimistic than what they had actually accomplished) and more a product of desiring some degree of geographic stability/security. Staying in Nuevo León meant staying put. This desire for stability was registered even though $43 \%$ of Profile $C$ students reported having a parent, sibling, and/or grandparent living in the United States at the time of our survey. Profile C students seemed less sure of returning to the United States than Profile A students. Two factors likely explain much of this discrepancy. First, many Profile $\mathrm{C}$ students were born in Mexico and thus may not have had U.S. citizenship or other rights to U.S. residency. Second, their short lives had already been highly mobile, chaotic, and unpredictable. Such experience could compel Profile $\mathrm{C}$ students to shy away from making confident prognostications about their futures. The birthplaces of Profile $\mathrm{C}$ students were diverse. Slightly less than a quarter $(24 \%)$ had been born in Nuevo León. About one in six had been born in Texas (17\%). The others had been born in California, Chihuahua, Colorado, Illinois, Mexico City, Michigan, New York, Oklahoma, Sonora, and Tamaulipas.

As a final point about Profile $\mathrm{C}$ students, they averaged the largest delay in their progress through school. On average, Profile $\mathrm{C}$ students were 0.6 years behind where they would have been had they progressed regularly through school. This delay illustrates one consequence of the 
limited articulation between schooling in the two countries-repeating a grade level. U.S. schools were not always preparing students to continue at grade-level when they enrolled in Mexico. Or, alternately, Mexican schools were not good at recognizing and accounting for lessons learned and content mastered in U.S. schools. ${ }^{5}$

That said, numerically more of the Profile B students (a larger group) had been delayed than Profile C students. Some Profile C students, accustomed to their mobility (or attending schools that were accustomed to mobility), had developed transition strategies to ameliorate their negotiation of the two systems. Some of the most mobile students used the documento de transferencia, a form recognized, as of 1996, in 10 of the 50 United States and in all 31 Mexican states that enables the crediting of experience in the previous country with the current one. Use of this form has been recommended since 1986 at various binational forums for educators (Dolson \& Villaseñor, 1996). Sixty-six percent of Profile C students used this document, compared to $15 \%$ of Profile A students and $19 \%$ of Profile B. The students with the greatest residential mobility also were the most educationally vulnerable, even though they were also the ones who appeared furthest along in developing strategies to respond successfully to their frequently changing circumstances.

\section{Welcome or Unwelcome in Mexican Schools}

Gaby was in her final year of secundaria (9th grade) when we met her. She had been born in Monterrey and brought to Chicago when she was four. She went to Chicago schools from Kindergarten through grade 8, but recently returned with her parents and one sibling to Nuevo León. Older siblings remained in Chicago working.

She told us she hopes to return to Chicago schools because the schools there "are wonderful, and everybody is good and helps you a lot." ${ }^{\text {. Gaby's }}$ experience in Chicago schools was rich. She especially valued the professionalism and the goodness of her teachers. She described a Filipina teacher who spoke Spanish and she described an Anglo teacher who wanted to learn Spanish and who asked her students to help her. Gaby could recall only one bad teacher, a teacher who punished those who spoke Spanish.

Gaby's description of how Illinois schooling is organized was very vivid. She described in detail the state's standardized exams, their frequency, and their importance for advancing. She also described the rites and rhythms of schooling in Chicago, relating clearly how teachers ask questions and what kinds of answers they expect, how they prepare students for exams, how many minutes one usually has to respond to a question, and even when it is time for a snack. In contrast, Gaby paints a much darker image of teachers and schooling in Mexico. She says Mexican teachers scold and punish students, offering little support. According to Gaby, the only thing Mexican teachers do is yelling at students. She said the teachers seem desperate because students will not quiet down nor do their schoolwork.

Gaby said she felt isolated in Mexico and wanted to return to Chicago, although she conceded that her younger brother (who was born in Chicago) was having a much more favorable experience in Mexico and had no interest in leaving. Gaby had not made friends during her five months back in Mexico. All of her friends were still in Chicago. She stayed in contact with them through the Internet and, occasionally, through a telephone call.

During our visit to Gaby's school, we were able to interview one of Gaby's teachers, Maestra López. The maestra taught Gaby's math and chemistry classes. Her descriptions (shared in a separate interview) were the opposite of what Gaby had offered. Maestra López knew that Gaby spoke Spanish well and that her mastery of that language was high, so she guessed that Gaby had been in a school in the sur (south) of the United States (presumably Texas) where teachers and students speak Spanish. Maestra López, who did not speak English herself, alleged that Gaby's level of English was poor. Maestra López, had never visited a U.S. school, but she was sure that the pace of math learning there was slow and explained why Gaby was having trouble with Mexican math. She also said Gaby was struggling even more with history (a subject that Maestra López did not teach): "Regarding [Mexican] history, she knows nothing."

Maestra López, did not think there should be a special program for transnational students. She suggested that they should be treated just like any other student. She also did not think it was necessary to talk with Gaby's parents. In fact, she did not even think it was necessary to talk individually with Gaby (except as she would individualize a comment, like "please sit down," with any student). Maestra López, claimed the only important thing is that transnational students integrate with their classmates. For them to succeed, you need to leave them alone, having them integrate little by little. "We can't shelter them... this [integration] is better for them.," For Maestra López, Gaby's background was incidental. Gaby was like any other student. The 'proof' was that she spoke Spanish like the other students (at least in Maestra López,'s estimation she did; Gaby had not been given a Spanish language proficiency test). Maestra López, could not envision what her student had described to us. Maestra López, was mono-national. Gaby was transnational. 
Gitlin et al. (2003) have described how U.S. school responses to newcomers can be concurrently welcoming and unwelcoming, welcoming by making an active accommodation to students' incomplete proficiency in English, for example, but being unwelcoming by not valuing such students' existing language skills or other "funds of knowledge" (González et al., 2005; Moll et al., 1993). Gaby's case suggests concurrent welcoming and unwelcoming can also occur for transnational students in Mexican schools. Many of her developed academic skills were not identified and found relevant by her Mexican teachers.

Also writing about the receptions that newcomers encounter in U.S. schools, Reeves (2004) has described a common teacher misconception that treating ELLs the same as other students equates with equal treatment. She highlights how treating students who are different as if they are not different is dismissive and that it represents a missed opportunity to be responsive to what students know and are engaged by. Maestra López grounds her refusal to differentiate her approach to Gaby as an issue of what would be most fair and helpful. What we observed (on Maestra López's part) was a rejection of difference: Gaby is not like the others; Gaby needs to be like the others. The dogma of a homogenous national identity in Mexico (Zúñiga 1998) has a clear manifestation in school practices and relations. Gaby's teachers do not know how many years Gaby attended school in Chicago. They do not know much about what she has studied, nor how well she did. Gaby's Mexican teachers appear to know practically nothing about her personal or educational history, but they do not find this absence problematic. From her teachers' perspective, Gaby is Mexican; she has no alternative. Part of who Gaby is is Mexican. She is welcome. But Gaby is not only Mexican and treating her as if that is all she is leaves out much that she knows and much that would engage her. She is also unwelcome.

\section{CONCLUSIONS}

If there are 10,000 U.S./Mexican transnational students in Nuevo León primarias and secundarias alone, then it should be obvious why the circumstances and educational trajectories of such students should be an object of inquiry - there are a lot of them. Moreover, such inquiry expands the interdisciplinary field of international migration studies and adds to fields like education policy, comparative education, equity studies, and teacher education. Returning to Glick-Schiller's (1999) notion of transnational facts, it does not seem accurate to consider the students we studied as only Mexican students (or only American ones), although some in our sample embraced each of these identities. Yet it seems equally inaccurate to view the data shared here as not describing a Mexican education story (and a partially American one). Most importantly, the data suggest that there are real issues related to school success (or lack thereof) and to identity formation and the interplay of schooling and transnationalism that should be of interest to many.

In brief, our study shows that transnational mobility can delay the academic progress of transnational students as well as their ability to form relationships with other students and with their teachers. It shows that many transnational students live in divided families in which important relations (a sibling, a parent, etc.) live in another country. Our study highlight that in Mexican schools there are students who see English as their first language and/or as a language they are competent in. There are students who would like to return to U.S. schools. There are students with favorable memories of their U.S. school experiences; students who are mostly but not entirely as favorably disposed to their Mexican school experience. Our study illustrates that there are U.S. citizens going to school in Mexico. And our study highlights that transnational students in Mexico are not homogenous (despite the shared biographical fact of at least one stint in U.S. schools). Most importantly, our study highlights that Mexico has transnational students and that learning from them can contribute to a broader understanding of transnational migration. All international migrants have been constructed by transnational fields that can be observed if researchers move from a nation-state paradigm to one where actors and processes go beyond borders and territories. The study of student trajectories allows researchers to consider what is not evident to most school actors both in Mexico and the United States. According to Velasco-Ortiz (2002), a transnational paradigm supports a new vision of international migration, supports an identification of how transnational actors become part of the fabric of daily life in an intangible and difficult to describe society where "here" and "there", "they" and "we", "local" and "national", "origin" and "destination" lose their dichotomous meanings.

This study can be used to raise some uncommon but important questions about educational policy and practice: How should schools respond to Profile A, Profile B, and Profile C transnational students? Should Mexican schools continue to so singularly presume that their task is to prepare students for Mexican adulthoods (only)? Should fourth grade in Tulsa Oklahoma be responsive to the prospect that one of their students (not 
necessarily one who would have been identified ahead of time) will be in school in Monterrey Mexico for fifth grade? What do Mexican teachers need to know to best serve transnational students? What should U.S. teachers expect if/when some of these students come back to them? What does it mean to best serve transnational students?

Ultimately, these final questions are as much political as investigative. But a portion of their best or most progressive answers can perhaps be derived from the strategies and habits developed by some of the transnational students themselves. Several of the students described here bypassed some of the "unwelcome" of their Mexican educational reception and used their "funds of knowledge" to find ways to maintain English language literacy skills, continuing to use English with siblings, for example, or recruiting a bilingual aunt to help with continued reading in English. Some of the students were carefully diligent in their maintenance of U.S.-based peer networks, strategies that could perhaps be useful if/when they and their families returned to Chicago, or Alabama, or Houston. Most importantly, and not necessarily as a conscious intention of their educators, many of these students subscribed to the idea that they needed to develop the necessary knowledge/literacy to negotiate well both sides of the U.S./Mexico border. These students were already leading transnational lives; as such, they were ahead of the educational systems they were part of in terms of trying to be ready for successful transnational adulthoods.

\section{NOTES}

1. A later phase of this research will occur in Zacatecas, a state in northern Mexico with a much higher rate of migration than Nuevo León.

2. Figuring that many in our sample would not know their legal citizenship status, we did not ask about it directly in our survey. However, given that there are other reasons than place of birth (e.g., citizenship of the mother) that can confer American citizenship, we know our $1 \%$ tally is likely an undercount.

3. The original quotes were offered in Spanish: "[El] ambiente en México es mejor que el de Estados Unidos" and "no estoy de acuerdo con mi mamá."

4. The girl's original quote is as follows, "Nos regresamos porque mi mamá es maestra de una escuela de Monterrey y tenía que regresar para jubilarse y no perder sus derechos de retiro."

5. The students in our sample who repeated a year were much more likely to do so in Mexico. (19 did so.) Perhaps this is just an artifact of our finding our sample in Mexico, which meant students had more years of Mexican experience than a transnational population found in the U.S. might have. (More years in Mexico than the U.S. would, by law of averages, make repeated years more likely to have occurred in Mexico.)
Alternately, perhaps the frequency of repeating in Mexico indicated that Mexican schools had fewer strategies for responding to students with atypical profiles (e.g., those with limited Spanish proficiency) than did U.S. schools (which are often accustomed to accommodating linguistic variation).

6. "[Las escuelas] están muy padres y todos son muy buenos contigo y te ayudan mucho."

7. "Porque no los podemos sobreproteger. . y eso, incluso, es más benéfico para ellos."

\section{REFERENCES}

Brettell, C. B. \& Hollifield, J. F. (2000). Migration theory: Talking across disciplines. New York: Routledge.

Crosnoe, R. (2005). Double disadvantage or signs of resilience? The elementary school contexts of children from Mexican immigrant families. American Educational Research Journal, 42, 269-303.

Cuadros, P. (2006). A home on the field: How one championship team inspires hope for the revival of small town America. New York: Rayo.

Dolson, D. P. \& Villaseñor, G. (1996). Migrant Education binational program. In J. LeBlanc Flores (Ed.) Children of La Frontera: Binational efforts to serve Mexican migrant and immigrant students (pp. 125-134). Charleston, WV: ERIC, Clearinghouse on Rural Education and Small Schools.

Dunn, T. (1996). The militarization of the U.S.-Mexico border, 1978-1992: Low-intensity conflict doctrine comes home. Austin: University of Texas Press.

Garcia, O. (1999). Educating Latino high school students with little formal schooling. In C. Faltis \& P. Wolfe (Eds.), So much to say: Adolescents, bilingualism, and ESL in the secondary school (pp. 61-82). New York: Teachers College Press.

Gándara, P., Rumberger, R., Maxwell-Jolly, J., \& Callahan, R. (2003, October). English learners in California schools: Unequal resources, unequal outcomes. Education Policy Analysis Archives, 11 (36). Retrieved May 6, 2005, from http://epaa.asu.edu/epaa/v 1 ln36/

Gitlin, A., Buendía, E., Crosland, K., \& Doumbia, F. (2003). The production of margin and center: Welcoming-unwelcoming of immigrant students. American Educational Research Journal 40(1), 91-122.

Glick-Schiller, N. (1999). Transmigrants and nation-states: Something old and something new in the U.S. immigrant experience. In C. Hirschman, P. Kasinitz, \& J. DeWind (eds.) The handbook of international migration. The American experience, (pp. 94-119). New York: Russell Sage Foundation.

Gozdziak, E. M. (2005). Beyond the gateway: Immigrants in a changing America: Immigrants in a changing America. Lanham, MD: Lexington Books.

Gómez de León, J. \& Tuirán, R (2000). Patrones de continuidad y cambio de la migración hacia Estados Unidos. In R. Tuirán (Ed.) Migración México-Estados Unidos, Presente y Futuro. México: CONAPO.

Goldring, L. (1992). La migración México-EUA y la transnacionalización del espacio político y social: Perspectivas desde el México rural. Estudios Sociológicos de El Colegio de México 10(29), 315-240. 
Gonzalez, N., Moll, L.C., Tenery, M. F., Rivera, A., Rendon, P., Gonzales, R., \& Amanti, C. (1995). Funds of Knowledge for teaching in Latino households. Urban Education 29(4), 443-470.

Gonzalez, N., Moll, L.C., \& Amanti, C. (Eds.) (2005). Funds of Knowledge: Theorizing practices in households and classrooms. Mahwah, NJ: Lawrence Erlbaum.

Goode, J. G., Schneider, J. A., \& Blanc, S. (1992). Transcending boundaries and closing ranks: How schools shape inter-relations. In L. Lamphere, (ed.) Structuring diversity: Ethnographic perspectives on the New Immigration, (pp. 173-213). Chicago: University of Chicago Press.

Guarnizo, L. E. (1998). The emergence of a transnational social formation and the mirage of return migration among Dominican transmigrants. Identities: Global Studies in Culture and Power, 4(2), 281-322.

Guerra, J. 1998 Close to Home: Oral and Literate Practices in a Transnational Mexicano Community. New York: Teachers College Press.

Hagan, J. M. (1994). Deciding to be legal: A Maya community in Houston. Philadelphia: Temple University Press.

Hamann, E. T. (2001). Theorizing the sojourner Student (With a Sketch of Appropriate School Responsiveness). In M. Carol Hopkins \& N. Wellmeier (Eds.) Negotiating Transnationalism: Selected Papers on Refugees and Immigrants, Vol. IX (pp. 32-71). Arlington, VA: American Anthropology Association.

(2003). The educational welcome of Latinos in the New South. Westport, CT: Praeger.

Hamann, E. T., Zúñiga, V., \& Sánchez, J. (2006). "Pensando en Cynthia y su Hermana: Educational Implications of U.S./Mexico Transnationalism for Children. Journal of Latinos in Education 5(4): 253-274.

INEE (2004). La Calidad de la Educación Básica en México 2004. México: Instituto Nacional para la Evaluación de la Educación. Retrieved October 20, 2005, from http://multimedia.ilce.edu,mx/inee/pdf/calidad2004.pdf

Kearney, M. 1996. Reconceptualizing the peasantry, Anthropology in global perspective. Oxford: Westview Press.

Lamphere, L. (Ed.) (1992). Structuring diversity: Ethnographic perspectives on the New Immigration. Chicago: University of Chicago Press.

López Castro, G. (1999) La educación en la experiencia migratoria de niños migrantes. In G. Mummert (Ed.) Fronteras fragmentadas, (pp. 359-374). Zamora, MICH, Mexico: El Colegio de Michoacán/CIDEM.

Massey, D., Alarcón, R., Durand, J., \& González, H. (1987). Return to Aztlán: The social process of international migration from western Mexico. Berkeley: University of California Press.

Massey, D., Durand, J., \& Malone, N. (2002). Beyond smoke and mirrors. New York: Russell Sage Foundation.

Moll, L. C., Tapia, J., \& Whitmore, K. F. (1993). Living knowledge: The social distribution of cultural resources for thinking. In G. Solomon, (Ed.), Distributed Cognitions: Psychological and Educational Considerations., pp. 139-163. Cambridge: Cambridge University Press.
Passel, J. (2006). The size and characteristics of the unauthorized migrant population in the U.S.: Estimates based on the March 2005 current population survey. Washington, DC: Pew Hispanic Center.

Pessar, Patricia. (1995). A Visa for a Dream: Dominicans in the United States. Boston: Allyn and Bacon.

Petron, M. A. (2003). I'm bien pocha: Transnational teachers of English in Mexico. Unpublished Dissertation. University of Texas at Austin.

Pries, L. 1998. Las migracions laborales internacionales y el surgimiento de espacios sociales transnacionales. Sociología del Trabajo. Nueva Época, 33, 103-129.

Reese, L. (2002). Parental strategies in contrasting cultural settings: Families in México and "El Norte." Anthropology \& Education Quarterly, 33(1), 30-59.

Reeves, J. (2004). "Like everybody else": Equalizing educational opportunity for English language learners. TESOL Quarterly, 38(1), 43-66

Reyes, X. A. (2000). Return migrant students: Yankee go home. In S. Nieto (Ed.), Puerto Rican students in U.S. schools (pp. 39-67). Mahwah, NJ: Lawrence Erlbaum Associates.

Sánchez García, J. (2007). El retorno de menores migrantes a escuelas de Nuevo León: Trayectorias escolares, identidades transnacionales, dinámicas de inclusiónlexclusión y trabajo docente. Unpublished dissertation, Universidad Autónoma de Nuevo León, Nuevo León, Mexico.

Secretaria de Educación Pública (2004). Sistema Educativo de los Estados Unidos Mexicanos, Principales Cifras, Ciclo Escolar 2003-2004. México: SEP, Subsecretaría de Planeación y Coordinación. Retrieved October 12, 2005 at: http://www.sep.gob.mx/ work/appsite/princcif2003/princcif2003.pdf

Serrano, 1. (1998). A comparative study of classroom coping behavior in the English and Spanish classes of return migrant and non-migrant Puerto Rican students. Educación (Aug.), 93-124.

Smith, R. C. 1998. "Transnational localities: Community, Technology, and the politics of membership within the context of Mexico-U.S. migration”. In M. P. Smith \& L. E. Guarnizo (Eds.) Transnationalism from below (pp. 196-238). New Brunswick, N.J.: Transaction Publishers,

Smith, M. P. \& Guarnizo, L. E. (eds.) 1998. Transnationalism from below. New Brunswick, N.J.: Transaction Publishers.

Súarez-Orozco, C. \& Súarez-Orozco, M. (2001). Children of immigration. Cambridge: Harvard University Press.

Trueba, E. T. (1998). The education of Mexican immigrant children. In M. M. SuárezOrozco (Ed.) Crossings, Mexican immigration in interdisciplinary perspectives ( $\mathrm{pp}$. 253-275). Cambridge: Harvard University Press.

Tuirán, R., Fuentes, C., \& Ávila, J. L. (2002) Indices de intensidad migratoria MéxicoEstados Unidos 2000. México: CONAPO.

Velasco-Ortiz, L. (2002). El regreso de la comunidad: migración indigena y agentes étnicos. México: El Colegio de México-El Colegio de la Frontera Norte.

Wortham, S., Murillo, E. G., \& Hamann, E. T. (Eds.) (2002). Education in the new Latino diaspora. Westport, CT: Ablex. 
Zúñiga, V. (1998) "Nations and Borders: Romantic Nationalism and the Project of Modernity", in David Spener and Kathleen Staudt (Eds.), The U.S.-Mexico Border: Transcending Divisions, Contesting Identities (pp. 35-55). Colorado: Lynne Rienner Publishers.

Zúñiga, V. \& Hernández-León, R. (Eds.) (2005). New Destinations: Mexican Immigration in the United States. New York: Russell Sage Books. 